\title{
STRATEGIES FOR FUNDING TECHNICAL VOCATIONAL EDUCATION AND TRAINING FOR ACHIEVING SUSTAINABLE NATIONAL DEVELOPMENT IN NIGERIA IN A POST-OIL BOOM ECONOMY
}

\section{Jane Itohan Oviawe}

\author{
Article History \\ Received: August 8, 2020 \\ Accepted: September 5, 2020 \\ Published: September 30, 2020
}

\section{Keywords}

Funding, technical vocational education and training, sustainable national development, post-oil boom economy

\author{
Department of Vocational and Technical Education, Ambrose Alli University, \\ Ekpoma, Edo State, Nigeria \\ Email: janeoviawe@aauekpoma.edu.ng
}

\section{INTRODUCTION}

Technical Vocational Education and Training (TVET) is recognized globally as education for self-reliance and fulfillment. It is the study of technology, related sciences and acquisition of practical skills, attitudes and knowledge relating to occupation in the various sectors of the economy and social life. TVET is aimed at providing skilled workforce in applied sciences, engineering, technology and commerce. It operates, maintains and sustains the nation's economic activities for rapid socio-economic development. To the Federal Republic of Nigeria (FRN) (2014), TVET is the aspect of education that leads to the acquisition of practical and applied skills as well as basic scientific knowledge. It is designed to facilitate the development of success in any occupation. TVET is a learning process that is practically-oriented and learning outcomes are determined through event practice of what is taught and learnt. It is one of the most powerful tools that will enable all recipients to face and handle challenges and also enables them to find roles as productive members of the society to which they are part. No country develops beyond the level of the human resources it possesses. According to Ogbuagu (2017), to develop industrially requires among others a workforce that has the right skills, knowledge, competencies and attitude of the workplace. Ogbuagu added that such workforce must be the products of TVET programmes. UNESCO (2015) posited that since education is considered the key to effective development, TVET must be the master key that can alleviate poverty, promote peace, conserve the environment, improve the quality of life for all and help improve the economy through the labour market outcomes. To Oviawe (2019), TVET enables individuals to acquire awareness, knowledge, skills and attitudes necessary for occupations in different sectors of economic and social life. She added that technological and industrial development of any nation requires a workforce that possesses the right skills, knowledge and attitude of the world 
of work. Such workforce must be the products of TVET programmes. This can only be possible by improving the quality of TVET programmes through adequate funding especially in a post oil boom era.

A boom is a period of rapid economic expansion resulting in higher GDP, lower unemployment and rising asset prices (thefreedictionary.com). Boom is a period of high economic growth characterized by rising wages, profits, full employment and high levels of investment, trade, and other economic activity (Collins, 2012). In the context of this study, a boom is a period of increased commercial activity within a business, market, industry or economy, a boom for a country is marked by significant GDP growth. Oil boom is a sudden increase in the wealth of a country as a result of the economic activities in the oil sector. Oil boom initially brings economic benefits in terms of increased GDP growth (Akpan \& Abasienie, 2017). Oil boom can also be seen as a period of dramatic change in the structure of the Nigerian economy which as a result of unprecedented boom in the drilling and exportation of oil which was driven by favourable market conditions that lead to large scale crude oil exploitation in the resource sector of the economy. The oil sector is a key sector in the Nigerian economy, this is because, the revenue from it is the main growth factor in the Nigerian economy. Resources generated from it, fund virtually all capital expenditures in the Nigerian system. This sector is closely linked with the financial sector because the financial sector in every nation is the oil that fuels the economy of such nation and the bedrock for the sustenance and continuity of the sovereignty of that nation.

Post-oil boom economy in Nigeria is the period when the prices of Nigeria's crude oil grades recorded significant decline. This post-oil boom has impacted disaster on the Nigerian economy system. The post oil boom economy describes an economy where there is a decrease in economic activities or wealth caused by depletion of mineral oil, crash in oil price, stiff competition among others. In Nigeria, the post oil boom economy surfaced from 1978 ("Oil Boom Era 1971-77”, n.d) following the problem of oil glut, foreign exchange difficulties and reduction/fluctuation in oil price and brought with it the following features: (i) underfunding of key sectors such as education, health, social service, infrastructure, and the likes; (ii) heavy dependence on foreign aids, grants and counterpart funding thereby compromising the independence status of the nation; (iii) declining income generating capacity due to reliance on oil revenue over time; (iv) surviving on external and internal borrowings without a guarantee of repayment; and (v) decrease in food production with a corresponding increase in consumption pattern.

\section{LITERATURE REVIEW}

Nigeria enjoyed the oil boom between the 1970s and the early 1980s. The consequence of the oil boom is the decline in the manufacture and productive sector of the economy (Zafar, 2004). The down turn in the economy as a consequence of the low price of oil in the global market then brought in what is referred to as the post-oil boom economy. The post-oil boom economy is characterized by poverty, unemployment and other social vices. The postoil boom economy requires the type of education that will equip citizens with the appropriate knowledge, skills and attitudes to live and survive the crunches placed on them by the economic meltdown. TVET is in the best place for the liberation of citizens from such economic problems. For TVET to achieve this goal, it must be adequately funded.

TVET is said to be capital intensive. The expensive nature of TVET does not lie with its recipients but also with its providers (government). To provide qualitative TVET programmes in Nigeria, Oviawe (2019) suggested that adequate budgetary provisions should be made by education providers. Agomuo and Enang (2014) asserted that the resources spent on education go a long way in determining the quality of education to be offered. But the Nigerian education sector has not received the kind of funding it deserves. This is because the budgetary allocation which is the main source of funding education in Nigeria has not met the $26 \%$ budgetary allocation stipulated by UNESCO. Aluede, Oviawe, Imhagbe, and Ehiaguina (2019) reported that the Nigerian Government in recent years have failed to meet the recommendations of UNESCO.

Funding is the act of providing funds or financial resources for a particular purpose on a continuous basis. Such funds should be adequate to cater for the programme for which they are provided. It is the act of providing money for a particular purpose (Hornby, 2012). The effective utilization of fund and other resources sustain development of any activity or programme. The attainment of TVET goals and objectives depend on proper planning, efficient administration and adequate funding (Ajoma, 2008). The current sources of funding TVET programmes in Nigeria are government grants, donations and fees; and these seem inadequate. The major role of government funding TVET programmes made it difficult to achieve effectiveness in its teaching and learning as a result of its capital intensiveness. To this end, Oviawe (2018) asserted that government alone cannot take on the responsibility of the 
task and that there is the need for public/private partnership in TVET. Similarly, the FRN (2014) having realized the huge burden of funding TVET stated in her national policy on education for the participation of the private sector, individuals and organizations to jointly fund education.

However, in spite of the efforts of government in funding of TVET programmes, it remains grossly inadequate. This inadequacy is due to the following reasons: inadequate budgetary provision from government and over dependence on government for funds; lack of financial commitment to the programme by stakeholders and poor gesture from the workplace. Hence, it is necessary to have proper funding TVET programmes towards the production of skilled graduates for sustainable development.

Sustainability is the state of having well balanced, steady and effective use of human material and capital resources for total economic independence and development of the nation (Nixon, 2005). Sustainable development is the organizing principle for meeting human development goals while at the same time sustaining the ability of natural systems to provide the natural resources and ecosystem services upon which the economy and society depends (Adamu, 2017). According to the World Commission on Environment and Development (1987), sustainable development is the development that meets the needs of the present without compromising the ability of future generations to meet their own needs. The adequate funding of TVET will help in sustainable development. TVET programmes require tools, equipment, machines and other facilities for teaching and learning. The importance of these facilities for overall success of any education programme is not contestable. Students are supposed to be trained with modern equipment to meet job demand after school. So, also TVET teachers need to be developed through attending locally, nationally and internationally organized conferences, workshops, and seminars, this require funds (Asuquo, 2013).

Oviawe (2018) posited that adequate provision of funds is a vital variable in the success of any education system. She added that funds provide the fundamental resources (purchasing power) for the system to acquire material and human resources. George and Liya (2005); Oviawe (2019) asserted that the following justify greater funding need of TVET programme: purchase of tools, equipments and machines; regular repairs and maintenance of equipment; manpower development; provision of consumables goods; equipping of library; salaries and allowance of staff; building of workshops and classrooms; security needs and research in TVET. Fafunwa (2010) stated that Nigeria has money but lacks the ability to use it judiciously. TVET holds the key for the solutions of Nigeria developmental problems, yet it is the worst applied instrument for national development (Dike, 2009).

TVET programmes require a lot of money for capital projects and overheads. Based on this, its funding cannot be over-emphasized. But unfortunately, TVET is not able to produce graduates with appropriate and saleable skills, abilities and competencies for employment because of the issue of inadequate funding that hinders the programme. Hence, if the financial challenge is not addressed as expected, it will hinder the teachers imparting necessary knowledge and skills in the students and adverse effects on the nation in general. Also, there is lack of equipment and other infrastructure and neglects of TVET in the budgetary allocation (Bamidele, 2007). This therefore requires innovative mechanisms for adequate funding of TVET programmes.

Innovative funding mechanisms are alternative ways to help enthrone efficiency and effectiveness in TVET programmes. These include: Ring-fenced TVET tax - a system where legal entity that is independent of the State or not controlled by the State should be in-charge and empowered to disburse funds to support apprenticeships and continuing vocational training; Skills development levy - a system where government by legislation is empowered to collect certain amount from public and private institutions which should be used to train people to fill skills shortages in identified workplaces (Mokwena, 2015). Other mechanisms according to Salmi and Hauphman (2006) are: academic facility user fees- where students are required to pay certain amount for maintenance and replacement of facilities they use for their practical training; Direct teaching cost - where students are charged for the direct teaching cost which is the cost required to run an academic department per student; Currency Transaction Levy (CTL) which is a method where government should be required to collect certain amount as tax for TVET on foreign exchange transaction' Air tickets solidarity levy or tax on airline tickets where government is required to collect certain amount as tax on airline tickets within the country and money collected is used to purchase TVET teaching and learning materials; VAT taxes generated by institutions offering TVET programmes - a percentage of the taxes from such institutions should be used to support TVET programmes.

Government allocates certain percentage of her annual budget to education. This mechanism is not ideal because TVET programmes are cost intensive compare to general education programme and the strategy of allocating the 
entire money under education does not give room for the funds to be allocated according to the needs of programmes. Strategy is a commitment to the set of principles, processes and practices of allocating the money. Innovative funding strategy promotes efficiency and effectiveness in TVET service delivery (Pisano, 2015).

Also, the innovative sourcing of TVET funding is the innovative allocation of funds to TVET programmes. For this to be achieved, funds should be allocated based on the following factors: Staff capacity building - when staff are exposed to seminars, conferences, workshops and quality research, their experiences should improve instructional delivery; procurement of facilities - when appropriate facilities such as print-based books, materials, laboratories, classrooms, libraries among others are made available, there should be improvement in teaching and learning; Student Industrial Training should be invested in to support and prepare students for work situations they will meet after graduation; Provision of seed money - certain amount of money should be set aside to defray cost on newlyaccredited programmes. Palmer (2019) stated that countries do not need to be concerned with raising enough funding to finance TVET reform, they need to make sure that the financing approaches themselves promote the goals of TVET reform. Mubanga, Hock, Karim and Mulenga (2019) asserted that some of the most appropriate sources of funding TVET and entrepreneurship education are: government grants, student fees (households), private sector investments, company contributions (skill levies), employee contributions (payroll based), internally generated income from services offered by TVET training providers and regulation fees, external assistance in the form of donor grants/NGO contributions and cooperating partners' loans.

\section{Statement of the Problem}

Unfortunately, the fund allocated to educational programmes in Nigeria is low. The issue is that distribution of funds is based on full-time equivalent (FTE) of students, which is based on students' enrolment. The use of student enrolment as the basis for allocating fund to support TVET programmes in public and private institutions to ensure that the cost per student per programme is the same in all institutions seems to be improper. To obtain the desired fairness, greater weights should be assigned to such programmes according to the needs and availability of funds. Incidentally, the sourcing, allocating and management of funds in TVET have been faced with issues. Government has remained the main source of financing TVET through grants, donations and fees (Agindota, 2016). This single source of funding does not help to effectively and efficiently prepare and develop people with relevant technical skills that are required in the ever dynamic world of work. The management in charge of allocating funds are also not helping issues in that funds are allocated according to students enrolment; this is not proper as TVET programmes requires very expensive tools, equipments, consumables and facilities. The single source of financing TVET calls for proactive attention and solution by developing strategies for adequate funding of TVET programmes.

\section{RESEARCH METHODS AND RESULTS}

The study adopted the descriptive survey research design in determining the strategies for funding TVET programmes in Nigeria for achieving Sustainable National Development in Post Oil Boom Economy in Nigeria.

The study was conducted in Edo State of Nigeria. The population for this study was 210 respondents comprising of all the 82 TVET lecturers in the tertiary institutions and TVET teachers 128 in the six technical colleges in Edo State offering TVET programmes. The sample for the study consisted of 137 respondents comprising of 35 lecturers from the three universities in Edo State offering TVET programmes: (18) Ambrose Alli University, Ekpoma owned by Edo State Government; (26) University of Benin, Benin City owned by the Federal Government, and (3) Benson Idahosa University, Benin City privately owned; 21 lecturers from polytechnics; 14 lecturers from colleges of education; 55 from technical colleges in Edo State who were purposively sampled.

The instrument used for data collection in this study was a 62 -item questionnaire developed by the researcher from literature reviewed. The questionnaire was structured on a five point Likert type scale. The instrument was subjected to face validation by three experts, two from the Department of Vocational and Technical Education and one in Test and Measurement, University of Benin, Benin City and Ambrose Alli University, Ekpoma both in Edo State. The suggestions and corrections of the experts were used to produce the final version of the instrument used for this study. Cronbach Alpha method was used to establish the internal consistency of the instrument and a reliability index of 0.88 was obtained. The instrument was administered by the researcher and five other research assistants. All the 137 copies of the questionnaire were duly completed and returned after two weeks. This gave a $100 \%$ return rate.

Factor analysis was used to answer the research questions while the ANOVA was used to test the null hypotheses at .05 level of significance and relevant degrees of freedom. For the research questions, any item with a factor loading 
of .05 and above was regarded as required while any item with a factor loading below .05 was regarded as not required. The null hypotheses were retained for any item whose P-value was greater than .05 but rejected when the P-value was below .05. SPSS version 24.0 was used to analyze the data collected.

\section{Results}

Research Question 1: What are the problems for funding of TVET programmes for sustainable development in post-oil boom economy in Nigeria?

Hypothesis 1: There is no significant difference in the mean ratings of TVET lecturers in universities, polytechnics, colleges of education and teachers in technical colleges on the problems for funding TVET programmes for sustainable development in post-oil boom economy in Nigeria.

Table 1. Summary of the outcome of Factor Analysis for answering research question 1 and ANOVA for testing hypothesis 1

\begin{tabular}{|c|c|c|c|c|c|c|}
\hline \multirow{2}{*}{$\mathbf{S} / \mathbf{N}$} & \multirow{2}{*}{ Problems of Funding } & \multirow{2}{*}{$\begin{array}{l}\text { Factor Loading } \\
\text { at .05 }\end{array}$} & \multirow{2}{*}{ P-value } & \multirow{2}{*}{ Sig. } & \multicolumn{2}{|c|}{ Remarks } \\
\hline & & & & & $\mathbf{R Q}$ & $\mathbf{H}_{\mathbf{0}}$ \\
\hline 1 & Inadequate budgetary provision. & .72 & .33 & .05 & A & NS \\
\hline 2 & $\begin{array}{l}\text { Government subvention has not kept pace } \\
\text { with students' enrolment. }\end{array}$ & .67 & .43 & .05 & A & NS \\
\hline 3 & $\begin{array}{l}\text { Lack of instructional materials for practical } \\
\text { classes. }\end{array}$ & .60 & .56 & .05 & A & NS \\
\hline 4 & Production of ill-equipped graduates. & .58 & .65 & .05 & A & NS \\
\hline 5 & Brain drain of highly qualified lecturers. & .78 & .44 & .05 & A & NS \\
\hline 6 & $\begin{array}{l}\text { Lack of commitments/collaboration by the } \\
\text { workplace. }\end{array}$ & .55 & .23 & .05 & A & NS \\
\hline 7 & Merger of TVET with general education. & .65 & .08 & .05 & A & NS \\
\hline 8 & Poor maintenance of the existing equipment. & .54 & .54 & .05 & A & NS \\
\hline 9 & $\begin{array}{l}\text { Sole funding of TVET programmes by } \\
\text { government. }\end{array}$ & .68 & .11 & .05 & A & NS \\
\hline 10 & Inadequate classrooms for students. & .62 & 69 & .05 & A & NS \\
\hline 11 & Ill equipped staff offices. & .59 & .21 & .05 & A & NS \\
\hline 12 & Poor instructional environment. & .59 & .32 & .05 & A & NS \\
\hline 13 & $\begin{array}{l}\text { Obsolete tools and equipment in TVET } \\
\text { laboratories and workshops. }\end{array}$ & .66 & .12 & .05 & A & NS \\
\hline 14 & Poor remuneration of TVET staff. & .75 & .16 & .05 & A & NS \\
\hline 15 & $\begin{array}{l}\text { Mismatch between TVET curriculum and the } \\
\text { demand of the workplace. }\end{array}$ & .64 & .83 & .05 & $\mathrm{~A}$ & NS \\
\hline 16 & $\begin{array}{l}\text { Non-availability of TVET } \\
\text { workshops/laboratories for practical lessons. }\end{array}$ & .63 & .49 & .05 & A & NS \\
\hline 17 & $\begin{array}{l}\text { Lack of electricity supply in TVET } \\
\text { institutions. }\end{array}$ & .51 & .55 & .05 & A & NS \\
\hline 18 & $\begin{array}{l}\text { Inadequate information and communication } \\
\text { technology facilities. }\end{array}$ & .58 & .21 & .05 & A & NS \\
\hline 19 & $\begin{array}{l}\text { Inadequate supply of machines and } \\
\text { equipment spare parts. }\end{array}$ & .61 & .67 & .05 & A & NS \\
\hline 20 & Corruption and misappropriation of fund. & .65 & .54 & .05 & A & NS \\
\hline
\end{tabular}

A = Agreed; NS= Not Significant

Table 1 reveals that factor loading of the 20-items listed as problems for funding TVET programmes for sustainable development in post-oil boom economy ranged from .51 to .78. This means that all the 20 items are perceived by the respondents as problems for funding TVET programmes for sustainable development in post-oil boom economy. Table 1 also revealed that each of the items had its P-value above .05. This implied that there was no significant difference in the Mean ratings of university lecturers, polytechnic lecturers, colleges of education lecturers and technical colleges' teachers on the problems for funding TVET programmes for sustainable development in post-oil boom economy. Therefore, the null hypothesis was retained. 
Research Question 2: What are the needs for funding of TVET programmes for sustainable development in post-oil boom economy in Nigeria?

Hypothesis 2: There is no significant difference in the mean ratings of TVET university lecturers, polytechnic lecturers, colleges of education lecturers and technical colleges' teachers on the needs for funding TVET programmes for sustainable development in post-oil boom economy in Nigeria.

Table 2. Summary of the outcome of Factor Analysis for answering research question 2 and ANOVA for testing hypothesis 2

\begin{tabular}{|c|c|c|c|c|c|c|}
\hline \multirow{2}{*}{$\mathbf{S} / \mathbf{N}$} & \multirow{2}{*}{ Needs for Funding } & \multirow{2}{*}{$\begin{array}{c}\text { Factor Loading } \\
\text { at } .05\end{array}$} & \multirow{2}{*}{ P-value } & \multirow{2}{*}{ Sig. } & \multicolumn{2}{|c|}{ Remarks } \\
\hline & & & & & RQ & $\mathbf{H}_{\mathbf{0}}$ \\
\hline 1 & $\begin{array}{l}\text { Achievement of TVET programmes goals } \\
\text { and objectives. }\end{array}$ & 77 & .56 & .05 & $\mathrm{R}$ & NS \\
\hline 2 & Proper planning and administration. & .56 & .32 & .05 & $\mathrm{R}$ & NS \\
\hline 3 & $\begin{array}{l}\text { Preparing and equipping lecturers and } \\
\text { students with necessary skills. }\end{array}$ & .57 & .51 & .05 & $\mathrm{R}$ & NS \\
\hline 4 & $\begin{array}{l}\text { Knowledge competency and skills required } \\
\text { for employment after graduation. }\end{array}$ & .50 & .37 & .05 & $\mathrm{R}$ & NS \\
\hline 5 & $\begin{array}{l}\text { Upgrading education leading to employment } \\
\text { achievement in occupations }\end{array}$ & .53 & .08 & .05 & $\mathrm{R}$ & NS \\
\hline 6 & Capital project and overheads. & .63 & .43 & .05 & $\mathrm{R}$ & NS \\
\hline 7 & $\begin{array}{l}\text { Production of skilled workforce for self- } \\
\text { reliance. }\end{array}$ & .52 & .21 & .05 & $\mathrm{R}$ & NS \\
\hline 8 & $\begin{array}{l}\text { Providing adequate confidence and safety in } \\
\text { service for sustainable development. }\end{array}$ & .64 & .43 & .05 & $\mathrm{R}$ & NS \\
\hline 9 & $\begin{array}{l}\text { Curriculum implementation with respect to } \\
\text { the content, instrument, tools and materials. }\end{array}$ & .67 & .39 & .05 & $\mathrm{R}$ & NS \\
\hline 10 & $\begin{array}{l}\text { Training of students with modern equipment } \\
\text { including emerging technologies to meet the } \\
\text { demands of the ever-dynamic workplace. }\end{array}$ & .59 & .45 & .05 & $\mathrm{R}$ & NS \\
\hline 11 & $\begin{array}{l}\text { Procurement of equipment and regular } \\
\text { maintenance of equipment. }\end{array}$ & .60 & .54 & .05 & $\mathrm{R}$ & NS \\
\hline 12 & $\begin{array}{l}\text { Updating and upgrading of TVET lecturers } \\
\text { for sustainable development. }\end{array}$ & .74 & .50 & .05 & $\mathrm{R}$ & NS \\
\hline 13 & $\begin{array}{l}\text { Provision of consumables materials such as } \\
\text { writing materials, fuel to power generators, } \\
\text { etc. }\end{array}$ & .72 & .67 & .05 & $\mathrm{R}$ & NS \\
\hline 14 & Provision of adequate security safe measure. & .59 & .54 & .05 & $\mathrm{R}$ & NS \\
\hline 15 & $\begin{array}{l}\text { Sustainable research efforts in TVET } \\
\text { programme. }\end{array}$ & .62 & .08 & .05 & $\mathrm{R}$ & NS \\
\hline 16 & Finding job after schooling outside. & .54 & .49 & .05 & $\mathrm{R}$ & NS \\
\hline 17 & $\begin{array}{l}\text { Expands its services to everyone in the } \\
\text { society. }\end{array}$ & .79 & .61 & .05 & $\mathrm{R}$ & NS \\
\hline 18 & Managing personal TVET affairs and policy. & .78 & .34 & .05 & $\mathrm{R}$ & NS \\
\hline 19 & Staff capacity building. & 67 & 67 & .05 & $\mathrm{R}$ & NS \\
\hline 20 & Students' industrial training support. & .56 & .51 & .05 & $\mathrm{R}$ & NS \\
\hline 21 & $\begin{array}{l}\text { Provision of seed money (newly accredited } \\
\text { programmes). }\end{array}$ & .67 & .43 & .05 & $\mathrm{R}$ & NS \\
\hline 22 & $\begin{array}{l}\text { Procurement of information and } \\
\text { communication technologies facilities. }\end{array}$ & .65 & .43 & .05 & $\mathrm{R}$ & NS \\
\hline
\end{tabular}

$\mathrm{R}=$ Required; NS= Not Significant

Table 2 reveals that all the 22-items on the needs for funding TVET programmes for sustainable development in post-oil boom economy in Nigeria had their factor loadings ranging from .50 to .79 which were either equal to or 
above .05 loading factor. This implied that all the items are needs for funding TVET programmes for sustainable development in post-oil boom economy in Nigeria. Table 2 also showed that all the items had their P-values above .05 at degree of freedom 3 and 100. This showed that there was no significant difference in the Mean ratings of TVET university lecturers, polytechnic lecturers, colleges of education lecturers and technical colleges' teachers on the needs for funding TVET programmes for sustainable development in post-oil boom economy in Nigeria. Therefore, the null hypothesis is retained.

Research Question 3: What are the strategies for sourcing funds for TVET programmes in tertiary institutions for sustainable development in post-oil boom economy in Nigeria?

Hypothesis 3: There is no significant difference in the mean ratings of TVET university lecturers, polytechnic lecturers, colleges of education lecturers and technical colleges' teachers on the strategies for sourcing funds for TVET programmes for sustainable development in post-oil boom economy in Nigeria.

Table 3. Summary of the outcome of Factor Analysis for answering research question 3 and ANOVA for testing hypothesis 3

\begin{tabular}{|c|c|c|c|c|c|c|}
\hline \multirow[b]{2}{*}{$\mathbf{S} / \mathbf{N}$} & \multirow{2}{*}{ Strategies for sourcing funds } & \multirow{2}{*}{$\begin{array}{l}\text { Factor Loading } \\
\text { at } .05\end{array}$} & \multirow{2}{*}{ P- value } & \multirow{2}{*}{ Sig. } & \multicolumn{2}{|c|}{ Remarks } \\
\hline & & & & & RQ & $\mathbf{H}_{\mathbf{0}}$ \\
\hline 1 & Grants from the Federal government. & .60 & .56 & .05 & $\mathrm{R}$ & NS \\
\hline 2 & Establishment of consultancy services. & .54 & .88 & .05 & $\mathrm{R}$ & NS \\
\hline 3 & $\begin{array}{l}\text { Appeal to be made to } \\
\text { personalities/philanthropic organizations. }\end{array}$ & .76 & 44 & .05 & $\mathrm{R}$ & NS \\
\hline 4 & $\begin{array}{l}\text { Appeal to Alumini associations, clubs, } \\
\text { religious bodies, etc. }\end{array}$ & .58 & .65 & .05 & $\mathrm{R}$ & NS \\
\hline 5 & Foreign assistance. & .65 & .08 & .05 & $\mathrm{R}$ & NS \\
\hline 6 & Periodic launching of programmes. & .54 & .54 & .05 & $\mathrm{R}$ & NS \\
\hline 7 & $\begin{array}{l}\text { Separation TVET from general education for } \\
\text { budgeting allocation to the programme. }\end{array}$ & .62 & .69 & .05 & $\mathrm{R}$ & NS \\
\hline 8 & Ring-fenced TVET Tax. & .59 & .21 & .05 & $\mathrm{R}$ & NS \\
\hline 9 & Skill development levy. & .68 & 11 & .05 & $\mathrm{R}$ & NS \\
\hline 10 & Currency transaction levy. & .55 & .23 & .05 & $\mathrm{R}$ & NS \\
\hline 11 & Air ticket solidarity levy. & 66 & .12 & .05 & $\mathrm{R}$ & NS \\
\hline 12 & Academic facility fee. & .59 & .32 & .05 & $\mathrm{R}$ & NS \\
\hline 13 & Introduction and increase in tuition. & .75 & .16 & .05 & $\mathrm{R}$ & NS \\
\hline 14 & $\begin{array}{l}\text { Annual contributions by the workplaces who } \\
\text { are the users of TVET graduates. }\end{array}$ & .64 & .83 & .05 & $\mathrm{R}$ & NS \\
\hline 15 & $\begin{array}{l}\text { Establishment and operation of TVET } \\
\text { commercial centres for sales and exhibition of } \\
\text { products. }\end{array}$ & .61 & .32 & .05 & $\mathrm{R}$ & NS \\
\hline 16 & $\begin{array}{l}\text { Donations of tools, equipment and machines } \\
\text { from TVET industries. }\end{array}$ & .63 & .65 & .05 & $\mathrm{R}$ & NS \\
\hline 17 & $\begin{array}{l}\text { Partnership in practical training between } \\
\text { TVET institutions and the workplace. }\end{array}$ & .53 & .22 & .05 & $\mathrm{R}$ & NS \\
\hline 18 & Public/Private Partnership & & & & & \\
\hline 19 & Increase in Government budgetary allocation. & .58 & .06 & .05 & $\mathrm{R}$ & NS \\
\hline 20 & $\begin{array}{l}\text { TVET institution to set up centres for } \\
\text { entrepreneurs skill acquisition. }\end{array}$ & .61 & .61 & .05 & $\mathrm{R}$ & NS \\
\hline
\end{tabular}

$\mathrm{R}=$ Required; NS= Not Significant

Table 3 revealed that all the items were rated by the respondents as required with factor loadings ranging from .53 to .76 which were above .50 loading factor; indicating that these 20 -items are perceived as by TVET educators as strategies for sourcing funds for TVET programmes for sustainable development in post-oil boom economy in Nigeria. Table 3 also revealed that all the 20 -items had their P-values ranging from .08 to .88 which were above .05 . This indicated that there was no significant difference between the Mean response of TVET university lecturers, polytechnic lecturers, colleges of education lecturers and technical colleges' teachers on the strategies for sourcing 
funds for TVET programmes for sustainable development in post-oil boom economy in Nigeria. Therefore, the null hypothesis was retained.

\section{Discussion of Findings}

The findings of this study revealed that all the items listed in Table 1 were perceived by the respondents as the problems of funding TVET programmes for sustainable development in post-oil boom economy in Nigeria. Testing hypothesis 1 , the results revealed that there was no significant difference in the Mean responses of university lecturers, polytechnic lecturers, colleges of education lecturers and technical colleges' teachers on the problems for funding TVET programmes for sustainable development in post-oil boom economy in Nigeria. This is in agreement with the assertion of Osuala (2004) that the problems of funding TVET programmes were because of inadequate budgetary provisions, the Federal Government being the sole funding, brain drain of highly qualified lecturers, lack of adequate classrooms and staff offices, and lack of teaching and learning equipment. The finding of this study is in line with the earlier findings by Mubanga, Hock, Karim and Mulenga (2019) who reported that lack of funding or inadequate funding were the causes of poorly resourced vocational institutions leading to inadequate tools, equipment, shortage of teaching materials in vocational schools and low motivation among the teaching staff.

Results presented in Table 2 revealed that there is a need for adequate funding of TVET programmes in Nigeria which enhances sustainable development of its graduates and delivery of its teachings. The finding of this study is in line with earlier findings of Okojie (2013) who reported that government under-funding affects the facilities to be provided for effective teaching, learning and research activities, type of teaching staff that can be engaged to undertake teaching and this definitely affects students' performance. Okojie added that the quantity and quality of learning resources to be provided make for a conducive learning is dependent on the volume of funds made available. This finding is in line with that of Ogbonnaya (2001) who justified the need of funding educational programmes. Similarly, Oviawe (2019) reported that the following justify greater funding need of TVET programme: purchase of tools, equipments and machines; regular repairs and maintenance of equipment; manpower development; provision of consumables goods; equipping of library; salaries and allowance of staff; building of workshops and classrooms; security needs and research in TVET is in support of the findings of this study.

Table 3 revealed that all the items were perceived by the respondents as strategies for sourcing funds for TVET programmes. This finding is supported by the earlier assertion of by Olaitan (1992) that the sources of funding TVET programmes include: grants from the Federal Government establishment of consultancy service, foreign assistance, donations from State Government and development levy by students. This finding is in line with that of Ajoma (2008) asserted that the strategies for sourcing funds from the Federal government and others help in the provision of equipment and other materials. Similarly, Ayo-Sobowale and Akinyemi (2011) asserted that with the level of underfunding in our educational institutions, there is need to evolve some strategies that will make it possible for universities to achieve qualitative education to support the findings of this study. To this end, Ike (2013) posited that gifts provided by friends will go a long way to assist in the provision of facilities and equipment which will make the teaching and learning of TVET easy, thereby producing high quality graduates of TVET. The findings of this study also revealed that ring-fenced TVET tax and skill development were sources of funding TVET. Supporting this finding, Mokwena (2015) stated that such innovative sources should make TVET effective and efficient. The finding of this study also revealed that academic facility user fees; direct teaching cost; currency transaction level; air tickets solidarity levy or a tax on airline tickets and VAT proceeds generated by TVET institutions were also sources of funding TVET. This is in line with the assertion of Salmi and Hauphman (2006) that there should be diversified funding methods in funding TVET programmes. Oviawe (2018) suggested that public private partnership between TVET institutions and the workplace. Ep-Nuffic (2016) remarked that in Indonesia, South Africa, Chili, Kenya, Colombia among others, alumni associations contributed significantly to the funding of TVET in 2015 to support the finding of this study. Mubanga, Hock, Karim and Mulenga (2019) asserted that some of the most appropriate sources of funding TVET and entrepreneurship education are: government grants, student fees (households), private sector investments, company contributions (skill levies), employee contributions (payroll based), internally generated income from services offered by TVET training providers and regulation fees, external assistance in the form of donor grants/NGO contributions and cooperating partners' loans corroborates the findings of this study. In agreement with the findings of this study, Palmer (2019) stated that there needs to be greater awareness that countries do not just need sufficient and predictable revenue streams to fund training programmes, but perhaps just as importantly 
they need to have in place appropriate financing mechanisms that are themselves strongly linked to achieving reform policy objectives.

\section{DISCUSSION AND CONCLUSION}

There is no gain saying that TVET is a practically suffused programme that requires vast funds for its implementation. For TVET to produce quality graduates with adequate technical and saleable skills; it must be well funded and all tools, equipment, machines, materials and educators must be on ground. The lone ranger effort of government in funding TVET has stifle its acceleration rather than bring us out of the woods especially in the post boil boom era. The truth is that government alone finds it difficult to fund TVET adequately. Hence, the need to determine alternative sources of funding is the way forward if TVET must achieve its objectives. This study found out various innovative sources and strategies to improve the funding of TVET programmes towards its effective delivery in Nigeria. It is fundamental that the identified sources and strategies of funding TVET programmes be implemented to ensure effectiveness and efficiency of programmes. Based on the findings of this study, the following recommendations were made:

1. Government and all stakeholders should adopt all the diverse strategies and sources of funding TVET programmes identified in this study for effective TVET delivery for sustainable development in post-oil boom era.

2. The administration of TVET programmes should be separated from other forms of education, if the objectives of sustainable development in TVET must be achieved. This will also ensure the effective utilization of the available funds for the programme.

3. TVET educators should be adequately and regularly remunerated to motivate them to put in their best on the job; and organize seminars, workshop, conferences on effective implementation of the strategies identified in this study.

4. TVET institutions should organize endowment fund raising to muster funds for the provision of tools, equipment and other facilities required fir TVET implementation.

5. TVET institutions should collaborate with the workplace in ensuring that TVET students acquire the requisite knowledge and practical skills for the world of work.

\section{REFERENCES}

Adamu, A. U. (2017). Education for sustainable development in Nigeria. International Journal of Studies in Education, 15(1), 1-17.

Agindota, J. T. (2016). Strategies for improving technical vocational education and training (TVET) in sustain national development: Implications on Business education. Department of vocational education (Business Education), School of Technical Education, Yaba College of Technology.

Agomuo, E. E. \& Enang, C. E. (2014). Funding administrative constraints affecting business education programme at the N.C.E. level in North Contral Zone of Nigeria. Nigerian Journal of Business Education, 2(2), 40-48.

Ajoma, U. C. (2008). Funding: A strategy for improving Business education in a globalized society. ABEN book of readings, 1(8), 29-36.

Akpan, N. A. \& Abasienie, S. B. (2017). Repositioning business education programme in Nigeria tertiary institutions for post-oil boom economy. Journal of Association of Vocational and Technical Educators of Nigeria (JAVETEN), 22(3), 97-104.

Aluede, O., Oviawe, J. I., Imhangbe, O. S., \& Ehiaguina, S. (2019). Nation Building and Quality Higher Education in Nigeria: Implications for Teacher Education. Africa Education Review, 17(2), 137-157. https://doi.org/10.1080/18146627.2018.1549952

Asuquo, E.E. (2013). Fundamental of vocational and technical education. Kano: Smith standard Nigeria limited.

Ayo-Sobowale, M. \& Akinyemi, S. (2011). Funding strategies for university education in Nigeria: The principle of fiscal justice. Journal of Studies in Education, 1(10), 1-13.

Bamidele, J. R. (2007). Developmental technical and vocational education in Nigeria: Imperative for youth empowerment in the $21^{\text {st }}$ century. Asaba Journal of Education Studies, 2(1), 82-86.

Collins English Dictionary - Complete and unabridged 2012 digital edition. Retrieved from www.dictionary.com/browse/boomer

Dike, V. E. (2009). Technical and vocational education: Key to Nigeria's development. Retrieved from http://www.triumphnenewspaoers.com/tech3032009.html 
Ep-Nuffic (2016). Annual report 2015. NFP and NICHE-programme. Retrieved from http://www.nuffic.nl/lec/ publications/find-a-publication/annual-report-2015-nfp-and-niche-programme.pdf

Fanfuwa, H. A. (2010). Classes are bid for failure before examination itself. The Nigeria Education Times, 30, 20-21.

Federal Republic of Nigeria (2014). National policy on education. Lagos: NERDC Press.

George, B. D. \& Liya, M. (2005). Strategies for funding and management of vocational and technical education in depressed economy. Paper presented at the school of education, Gidan-Waya on the $29^{\text {th }}$ of September.

Hornby, A. S. (2012). Oxford advanced learning dictionary of current English. London: Oxford University Press.

Ike, G. A. (2013). The use of information and communication technology (ICT) in teaching and learning in the school. A paper presented at the international conference of the centre for promotion of continental studies and development. Held at the Basic Hall University of Ghana, Legon, Accra on $29^{\text {th }}$ March.

Mokwena, L. (2015). Money counts: Financing technical and vocational education and training in the post-2015 education for All Agenda. Retrieved from www.aaionline.org/money-counts-financing-technical-andvocational-education.

Mubanga, P., Hock, O. Y., Karim, A. M. \& Mulenga, I. M. (2019). Methods of financing technical and vocational education and training, and entrepreneurship education to support skills development in Lusaka Province, Zambia. International Journal of Research and Scientific Innovation (IJRSI), VI(VI), 96-107.

Nixon, M. (2004). Oxford English dictionary. New York: Oxford University Press.

Ogbonnaya, N. I. (2001). Foundations of educational finance. Onitsha: Caps Publishers International Limited.

Ogbuagu, J. O. (2017). Information and communication technology (ICT) and technical vocational education and training (TVET) instructional delivery for the $21^{\text {st }}$ century. Lead paper presentation at the national conference of the Nigerian Vocational Association held at the University of Nigeria Nsukka from $3^{\text {rd }}$ to $6^{\text {th }}$ of May, 2017.

Oil Boom Era (1971-77). Online Nigeria.com. Retrieved from http://www.OIL\%20BOOM\%20ERA\%20(197177)\%20\%20OnlineNigeria.com

Okojie, J. A. (2013). Quality assurance and the challenge of mandate delivery in the Nigerian university system. A special address presented at the Lagos State university $18^{\text {th }}$ convocation lecture, Lagos State, Nigeria held on the $19^{\text {th }}$ of February.

Olaitan, S. O. (1992). The crisis of funding vocational technical education programme. Lagos: University of Lagos Press.

Osuala, E. C. (2004). Foundation of vocational education. Enugu: Cheston Agency limited.

Oviawe, J. I. (2018). Revamping technical, vocational education and training through public-private partnerships for skill development. Makerere Journal of Higher Education, 10(1), 73-91. http://dx.doi.org/10.4314/ majohe.v10i1.3

Oviawe, J. I. (2019). Funding technical, vocational education and training programmes for sustainable national development in Nigeria. In: Oyeweso, S. \& Aworanti, T. (Eds.). Technical and Vocational Education and the challenge of development in Nigeria. Osogbo: Atman limited.

Palmer, R. (2019). Financing technical and vocational skills development reform. In: McGrath, S., Mulder, M., Papier, J., \& Suart, R. (eds.), Handbook of vocational education and training. Switzerland: Springer, Cham. https://doi.org/10.1007/978-3-319-94532-3_42

Pisano, G. P. (2015). You need innovative strategy. Retrieved from https://hbr.org/2015/06/you-need-an-innovativestrategy

Salmi, A. \& Hauphman, A. M. (2006). Innovative in tertiary education funding: A comparative evaluation of allocation mechanisms. World Bank, 4-60.

World Commission on Environment and Development (1987). Our common future. Oxford: Oxford University Press.

Zafar, A. (2004). What happens when a country does not adjust to terms of trade shocks. Retrieved from https://books.google.com 